Article

\title{
The Spanish Version Of The Child Medical Fear Questionnaire: Cross-Cultural Adaptation And Validation
}

\author{
Leticia San Martín-Rodríguez ${ }^{1}$, Nelia Soto-Ruiz 2,*, Marta Ferraz-Torres ${ }^{3}$, Cristina García-Vivar ${ }^{4}$, Amaia \\ Saralegui-Gainza ${ }^{5}$, Paula Escalada-Hernández ${ }^{6}$
}

1 Associate professor, Department of Health Sciences, Public University of Navarre (UPNA). Avda. Barañain s/n, 31008, Pamplona, Navarra. Spain. IdiSNA, Navarra Institute for Health Research. C/ Irunlarrea, 3, 31008. Pamplona, Navarra. Spain; leticia.sanmartin@unavarra.es

2 Associate professor, Department of Health Sciences, Public University of Navarre (UPNA). Avda. Barañain s/n, 31008, Pamplona, Navarra. Spain. IdiSNA, Navarra Institute for Health Research. C/ Irunlarrea, 3, 31008. Pamplona, Navarra. Spain2; nelia.soto@unavarra.es

3 Lecturer, Department of Health Sciences, Public University of Navarre.Avda. Barañain s/n, 31008, Pamplona, Navarra. Head unit of training and research, Navarra Hospital Complex. C/Irunlarrea s/n, 31008, Pamplona, Navarra; marta.ferraz@unavarra.es

4 Senior associate professor, Department of Health Sciences, Public University of Navarre (UPNA). Avda. Barañain s/n, 31008, Pamplona, Navarra. Spain. IdiSNA, Navarra Institute for Health Research. Irunlarrea, 3 , 31008. Pamplona, Navarra. Spain; cristina.garciavivar@unavarra.es

5 Department of Health Sciences, Public University of Navarre. Avda. Barañain s/n, 31008, Pamplona, Navarra. Spain; amaia.saralegui@gmail.com

6 Associate professor, Department of Health Sciences, Public University of Navarre (UPNA).Avda. Barañain s/n, 31008, Pamplona, Navarra. Spain. IdiSNA, Navarra Institute for Health Research. C/ Irunlarrea, 3, 31008. Pamplona, Navarra. Spain; paula.escalada@unavarra.es

* Correspondence: nelia.soto@unavarra.es; Tel.: +34 948161117. 


\begin{abstract}
:
Having valid and reliable tools that help health professionals to assess fear in children undergoing medical procedures is essential to offer humanized and quality of care in the paediatric population. The aim of this study was to develop the cross-cultural adaptation and the evaluation of the psychometric properties of the Spanish version of the "Child Medical Fear Scale" in its shortened version (CMFS-R). The design consisted of two phases, first of cross-cultural adaptation and second of the psychometric validation of the CMFS-R with a sample of 262 children from Spain. Confirmatory factor analysis was conducted to assess construct validity and the Cronbach alpha and the adjusted item-total score correlation coefficients were performed to study reliability. The results confirmed internal consistency and construct validity of the Spanish version of the CMFS-R, indicating that the scale has an acceptable level of validity and reliability. Therefore, this study brings a new version of the scale to assess fear related to medical procedures for use in the Spanish paediatric population.
\end{abstract}

Keywords: medical fear; children; psychometric properties; cross-cultural adaptation; Spanish

\title{
1. Introduction
}

Most children are afraid of coming into contact with the healthcare environment, be it to see the doctor, go to the emergency room or hospital wards. Consequently, for the past few years, in the context of humanising healthcare, an attempt was made to make spaces visited by children look more attractive, featuring children's themes, background music, toys and even healthcare professionals have begun to wear coloured uniforms to care for their younger patients [1,2].

The greatest fear for boys and girls visiting a doctor's surgery or who have to go into hospital is being separated from their family, receiving injections for the different procedures and having to be in hospital for a long time [3-5].

Fear is an innate response that is regulated with maturity and that depends on each child. It is defined as a specific biological and psychological response to something real or imaginary [6]. Specifically, medical fear is defined as "fear of any experience that involves medical personnel or procedures involved in the process of evaluating or modifying health status in traditional health care settings" [7] (p. 10).

In 1988, Broome and colleagues [8,9] developed the "Child Medical Fear Scale" (CMFS) that, with 29 items, measured medical fear among children. The CMFS has demonstrated appropriate internal consistency, reliability, criterion and discriminant validity $(3,10-14]$. In relation to internal consistency reliability, the Cronbach's $\alpha$ coefficient was greater than 0,70 in several studies, ranging between 0.93 and 0.78 [3,10-14].

Years later, the scale was reviewed and redundant items and items that showed little variability were eliminated, obtaining a 17-item scale (CMFS-R) [15]. The items included in the scale express statements of fear regarding certain aspects related to the health environment, which the child must answer according to a Likert-type scale with three points: not at all ( 0 points), a little ( 1 point) and a lot ( 2 points). So, the maximum level of fear is represented with a score of 34 points and the minimum level with zero points [11].

The discriminant validity of CMFS-R with pain measures was confirmed by Beyer and Knott [10] and Sparks [16]. Regarding the construct validity, the original CMFS-R scale demonstrated that it had a 4-factor structure, that referred to medical procedural fears, health care environmental fears, intrapersonal fears (own bodies) and interpersonal fears (interaction with healthcare professionals) [11,17]. In their translation of the CMFS-R into Dutch, Abu-Saad et al. [18] determined the existence of two factors (environmental fears and procedural fears) that explained $30 \%$ of the variance, while in their translation into Thai, Chaiyawat \& Brown [19] identified three factors (fear of physical hurt, fear of loss of control and interpersonal fears] that explained $42.15 \%$ of the variance.

The CMFS-R has been translated into three languages: Dutch [18], Thai and Chinese 
$[11,19]$. However, to date, no study has determined the psychometric properties of a Spanish version of the scale. Therefore, the aim of this study was to develop the crosscultural adaptation and the evaluation of the psychometric properties of the Spanish version of the "Child Medical Fear Scale" in its shortened version.

\section{Materials and Methods}

This methodological study was performed in two stages: a first stage to translate the original instrument into Spanish and a second stage to analyse the psychometric properties of the Spanish version of the instrument.

\subsection{Phase I: cross-cultural adaptation}

Firstly, the statements for the instrument were translated and back-translated following the method proposed by Brislin [20]. Consequently, a native Spanish-speaker, who was familiar with the terminology being used, made an initial translation of the questionnaire into Spanish. An evaluation of the translation, to determine the equivalence of meaning for the items in the two questionnaires was carried out by four nurses who spoke the original questionnaire language, were also native Spanish-speakers and were familiar with the specific terminology in the questionnaire.

Secondly, to ensure linguistic validation [21], another bilingual person, independent from the first, who was a native English-speaker specialised in healthcare sciences performed the back translation from Spanish to English. Subsequently, a comparison was made between the original version of the questionnaire and the back translation, using a panel of experts who discussed the differences they found. This panel included four nurse researchers with experience in cross-cultural adaptation of instruments and pediatric nurses.

Thirdly, the questionnaire was piloted to verify the applicability of the instrument and the quality of the translation. To do this, a total of 5 children of different ages were selected to take the pretest on item comprehension. They were asked to indicate any items that might be confusing and to suggest an alternative when appropriate.

\subsection{Phase II: Psychometric validation}

In a second stage, an evaluation was performed on the degree of validity and homogeneity of the questionnaire, by determining the content validity and the internal consistency of the statements.

\subsubsection{Sample}

The sample included 262 children, aged between 6 and 10 years old, from 4 randomly selected schools in the city of Pamplona, in Spain. This sample size meets Nunnally's recommendations for this type of analysis, which suggests using at least 10 subjects per item [22].

The children included in the sample had similar characteristics regarding their previous contact with the healthcare environment. The majority of them had experienced some of the common childhood illnesses and did not present serious pathologies.

\subsubsection{Data collection}

The data was collected using an online survey tool. An electronic questionnaire was created that included the 17 items in the CMFS-R questionnaire and two sociodemographic questions (age and gender). The children completed the questionnaire through a survey web tool (SurveyMonkey) using tablets in the classroom during class time. The students were given the necessary instructions to understand the task that was requested and they were forbidden to speak during this time, which were monitored by the class teacher. 


\subsubsection{Data analysis}

Confirmatory factor analysis (CFA) was performed using LISREL 9.2 software. The aim was to use a series of structural linear equations to score the degree of adjustment for the data obtained via the Spanish version of the questionnaire, to the two known factorbased structures of the instrument: a 4-factor structure and another with 3 factors. Taking into account the ordinal nature of the data, the analysis was based on the polychoric correlation and asymptotic variance-covariance matrices [23-26]. The weighted least squares method was used to determine the model adjustment, as suggested by Jöreskog [25] when referring to ordinal data. The global fit of two conceptual structures to the data was evaluated using a set of indices [27]. The indices used were Reason for fit (Pearson Chisquared/degrees of freedom), RMSEA (Root Mean Square Error of Approximation), SRMR (Standardized Root Mean square Residual), Tucker-Lewis index (TLI), Goodness-Of-Fit Index (GFI) and Comparative Fit Index (CFI) [27,28].

In addition, Cronbach's $\alpha$ and the adjusted item-total score correlation coefficients were calculated to analyse internal consistency. These analyses were performed using SPSS 25.0 statistical software.

\subsubsection{Ethical considerations}

This study received approval from the Committee of Ethics, Animal Experimentation and Biosafety of the Public University of Navarre (PI-030/19). Written informed consent was obtained from the parents or legal guardians of the children. The collected data was anonymous since the data collected does not include the IP from which the survey was carried out. The confidentiality of the data was ensured by generating an identification code for each one of the participants and thus, no personal data was recorded.

\section{Results}

\subsection{Phase I: cross-cultural adaptation}

As a result of the first stage of the study, a scale in Spanish that is equivalent to the original in English from a linguistic point of view was obtained (see Appendix A).

After translation and back-translation of the items, the panel of experts identified one item that caused difficulty when interpreting its content. This item was "I am afraid of having my finger stuck", whose literal translation in Spanish could result in different interpretations including trapping your finger in a door, having your finger "pinched" in a pulse oximeter, or having your finger stabbed to get capillary blood. After consulting the literature on the scale, it was decided to modify how the item was written to give it this latter meaning.

Finally, the pilot test of the instrument showed that the understanding of one of the items by the participating children was adequate. Only one child noted that he did not know the meaning of the term "tongue blade". The alternative "stick" (in Spanish: "palito") was given for this term, thereby solving the comprehension problem. Taking this into account, it was decided to maintain the term "tongue blade" in the scale item, but that the child's age would be considered, putting "stick" in brackets to clarify the term for younger children.

\subsection{Phase II: psychometric validation}

Firstly, the results from Barlett's sphericity test $(\mathrm{p}<0.001)$ and the Kaiser-MeyerOlkin sample adequacy test $(0.886)$ confirmed that the data were appropriate to carry out a factor-based analysis.

Table 1 presents the indices obtained from the CFA for the 4- and 3-factor structure that shows that the data adjust better to the 4 -factor structure. However, according to the high correlation found among the 4 factors, it could be thought that there may exist a more 
general construct that underlies the 4 factors. Thus, a hierarchical CFA was performed by introducing one general factor as second-order factor. The results of the fit indices show a slightly worse fit for this model, therefore the 4-factor structure was chosen as it was the most appropriate.

Table 1. Indices

\begin{tabular}{|l|l|l|l|l|l|}
\hline \multicolumn{2}{|l|}{ Indices } & Good fit & 3 factor & 4 factor & $1 \times 4$ factor \\
\hline Reason for fit & $\chi 2 /$ df & from 2 to 6 & 2.72 & 2.45 & 2.51 \\
\hline $\begin{array}{l}\text { Root mean square } \\
\text { error of aproximation }\end{array}$ & RMSEA & $<0.08$ & $\begin{array}{l}0.081 \\
(0.070-0.093)\end{array}$ & $\begin{array}{l}0.075(0.063- \\
0.086)\end{array}$ & $\begin{array}{l}0.076 \quad(0.065- \\
0.087)\end{array}$ \\
\hline $\begin{array}{l}\text { Standarized root } \\
\text { mean square residual }\end{array}$ & SRMR & $<0.08$ & 0.065 & 0.064 & 0.064 \\
\hline Tucker-Lewis index & TLI & $>0.90$ & 0.92 & 0.94 & 0.94 \\
\hline Goodnes-of-fit index & GFI & $>0.90$ & 0.88 & 0.89 & 0.88 \\
\hline Comparative fit index & CFI & $>0.90$ & 0.93 & 0.95 & 0.95 \\
\hline
\end{tabular}

The items are distributed among the 4 factors as follows: Factor I, Intrapersonal, includes four items: I am afraid of (1) hurting myself, (4) seeing blood come out of me, (8) throwing up and (10) what I will say when I hurt. Factor II, Procedural, consists of five items: I am afraid of (2) going to the doctor's office, (3) getting a shot, (6) having my finger stuck, (14) having the doctor or nurse look down my throat and (17) the doctor or nurse putting a tongue blade in my mouth. Factor III, Environmental, comprises four items: I am afraid of (5) going to the hospital, (11) if I went to the hospital I would have to stay a long time, (13) I might die if I go to the hospital and (16) being away from my family if I go to the hospital. Factor IV, Interpersonal, incorporates four items: I am afraid that (7) the doctor and nurse will not tell me what they are going to do to me, (9) missing school if I'm sick, (12) my friends/family will catch something I have if I'm sick and play with them, and (15) the nurse or doctor will tell me something is wrong with me [11].

On the other hand, figure 1 shows the estimated values for each of the parameters and the corresponding standard errors for each of the 17 items on the questionnaire, according to the 4 -factor structure. In addition, the coefficients of determination $\left(\mathrm{R}^{2}\right)$ for all 17 items vary in a range between 0.12 and 0.51 . 


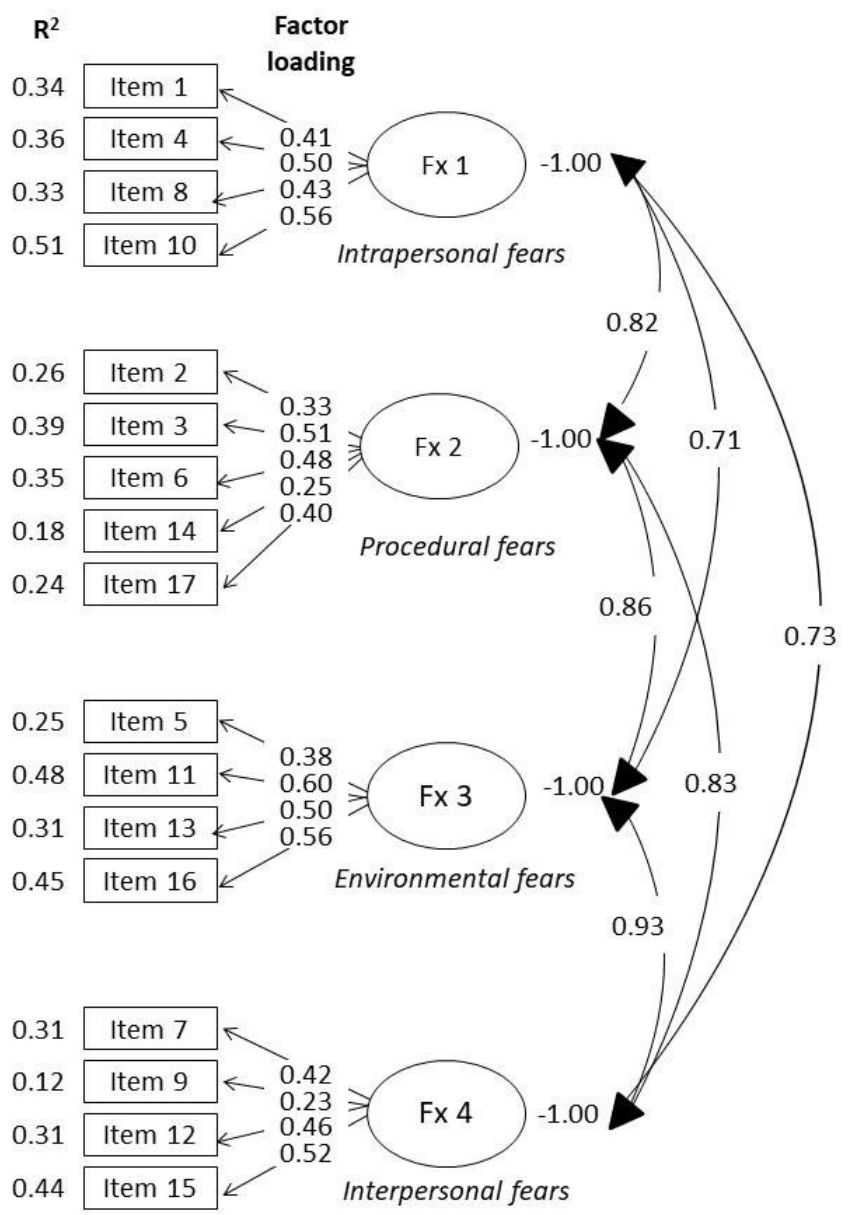

Figure 1. CFA for the 4 factor structure.

Finally, the evaluation of the internal consistency of the instrument attained a Cronbach's $\alpha$ of 0.87 . The adjusted item-total score correlation coefficients varied between 0.355 and 0.612 .

As it is presented in table 2, the evaluation of the internal consistency of the 4 factors present Cronbach's $\alpha$ coefficients between 0.60 and 0.70 . In the same table, the Cronbach's $\alpha$ coefficients with the item removed and the adjusted item-total score correlation coefficients are described.

Table 2. The evaluation of the internal consistency of the instrument

\begin{tabular}{|l|c|c|c|}
\hline & $\begin{array}{c}\text { Cronbach's } \alpha \\
\text { coefficient }\end{array}$ & $\begin{array}{c}\text { Cronbach's } \alpha \\
\text { with the item } \\
\text { removed }\end{array}$ & $\begin{array}{c}\text { Corrected } \\
\text { item } \\
\text { total }\end{array}$ \\
\hline Factor I: Intrapersonal & 0.70 & & \\
\hline 1.Tengo miedo a hacerme daño. & & 0.86 & 0.55 \\
\hline 4.Tengo miedo a ver cómo me sale sangre. & & 0.86 & 0.47 \\
\hline
\end{tabular}




\begin{tabular}{|c|c|c|c|}
\hline 8.Tengo miedo a vomitar. & & 0.86 & 0.48 \\
\hline $\begin{array}{l}\text { 10.Tengo miedo a llorar cuando me hagan } \\
\text { daño. }\end{array}$ & & 0.86 & 0.55 \\
\hline Factor II: Procedural & 0.66 & & \\
\hline 2.Tengo miedo a ir a la consulta del médico. & & 0.86 & 0.47 \\
\hline 3.Tengo miedo a que me pinchen. & & 0.86 & 0.52 \\
\hline $\begin{array}{l}\text { 6.Tengo miedo de que me pinchen en el } \\
\text { dedo. }\end{array}$ & & 0.86 & 0.50 \\
\hline $\begin{array}{l}\text { 14.Tengo miedo cuando el médico o la } \\
\text { enfermera miran mi garganta }\end{array}$ & & 0.87 & 0.43 \\
\hline $\begin{array}{l}\text { 17.Tengo miedo cuando el médico o la } \\
\text { enfermera apoyan el palito en mi lengua. }\end{array}$ & & 0.87 & 0.43 \\
\hline Factor III: Environmental & 0.69 & & \\
\hline 5.Tengo miedo a ir al hospital. & & 0.86 & 0.47 \\
\hline $\begin{array}{l}\text { 11.Si voy al hospital, tengo miedo a tener que } \\
\text { quedarme mucho tiempo allí. }\end{array}$ & & 0.86 & 0.61 \\
\hline 13.Tengo miedo a morirme si voy al hospital. & & 0.86 & 0.48 \\
\hline $\begin{array}{l}\text { 16.Tengo miedo a estar lejos de mi familia si } \\
\text { voy al hospital. }\end{array}$ & & 0.86 & 0.56 \\
\hline Factor IV: Interpersonal & 0.60 & & \\
\hline $\begin{array}{l}\text { 7.Tengo miedo a que los médicos y las } \\
\text { enfermeras no me digan lo que me van a } \\
\text { hacer. }\end{array}$ & & 0.86 & 0.45 \\
\hline $\begin{array}{l}\text { 9.Tengo miedo a no ir al colegio si me pongo } \\
\text { malo. }\end{array}$ & & 0.87 & 0.35 \\
\hline $\begin{array}{l}\text { 12.Tengo miedo a contagiar a mi familia o } \\
\text { amigos si estoy enfermo y juego con ellos. }\end{array}$ & & 0.86 & 0.50 \\
\hline $\begin{array}{l}\text { 15.Tengo miedo a que el médico o la } \\
\text { enfermera me digan que me pasa algo malo. }\end{array}$ & & 0.86 & 0.57 \\
\hline
\end{tabular}

\section{Discussion}

The aim of this study was to complete the validation process of the Spanish version of the CMFS-R, originally developed by Broome and Mobley [11] to assess children's fear related to healthcare situations such as diagnostic or therapeutic procedures, hospitalization or surgery [12]. This research has evaluated both internal consistency and construct validity, in addition to its factorial structure through a confirmatory factor 
analysis. Our findings confirm that the Spanish version of the CMFS-R has been proven valid and reliable for its use in the Spanish context. The scale was easy to understand and took only around 7 minutes to complete.

The process of translating and back-translating the CMFS-R into Spanish was undertaken in accordance with established guidelines $[20,21]$ to ensure content equivalence between the original and translated versions. The pilot process made it possible to ensure the applicability of the instrument and the adaptation of the translated terms that might generate the most difficulty for users to interpret such as the item "I am afraid of having my finger stuck", ensuring that the translation is useful and valid. During data collection however, it was seen that the youngest children occasionally found it hard to understand the term "tongue blade" ("depresor" in Spanish). In this case, this was not due to translation issues, but due to lack of medical terminology knowledge among the younger participants. When the scale is used in the future, to ensure correct comprehension of this item, it is recommended to include a colloquial expression for tongue blade in brackets, such as stick ("Palito" in Spanish). The difficulty with the medical terminology for school age children has been observed in a range of studies [29,30].

At this point, it should be mentioned that the Spanish used for the scale translation is Spanish spoken in Spain. In other Spanish-speaking countries, particularly in Central America and South America, the Spanish features different expressions and terms, so to use it in these contexts, it would be necessary to adapt for language and culture.

The results of the confirmatory factor-based analysis have demonstrated that the Spanish version of the CMFS-R is a slightly better fit for the 4-factor structure proposed for the original questionnaire [11] (even with a 4-factor structure with a general factor), compared to the 3-factor structure in the Chaiyawat's study for the Thai translation [19]. Although Abu-Saad et al. [18] identified a 2-factor structure in the Dutch version of the CMSF-R, this structure was not included in the CFA because information about the items within each factor was not available.

Out of the four factors, Factor I, Intrapersonal, and Factor II, Procedural, encompass items related to unpleasant feelings such as pain or healthcare staff carrying out certain procedures. The items grouped into these two factors reflect the phobic agents classified in the blood-injection-injury phobias category listed by DSM-5 [31]. Factor III compiles factors referring to hospitalisation. The literature demonstrates that hospitalisation can be a particularly stressful experience for children due to their incomplete cognitive development, limited understanding of their disease or lack of strategies to deal with it $[12,31,32]$. Furthermore, the fear could increase as a consequence of being in an unknown environment [5]. Two of the items within Factor IV, Interpersonal, are related to the information provided by healthcare professionals. Several studies concluded that children wanted to know what was expected of them during consultations or procedures and what was going to happen to them then [33-35]. Even being with people they do not know generates fear [5].

Regarding the reliability of the instrument, the results show a good level of reliability. On the one hand, the Cronbach's alpha located at 0.87 , higher than the 0.70 set as satisfactory by Nunnally [22], indicates that $87 \%$ of the instrument variance is systematic, in other words, it represents the real differences between individuals regarding the perception of medical fear, while in $13 \%$ it is due to random error [36,37]. The values of Cronbach's $\alpha$ for each of the dimensions range between 0.60 and 0.70 , three of them slightly below the reference value of 0.70 . The lower number of items is an important limit to achieve a good level of internal consistency, as this is not based exclusively on the average correlation among items, but also on the number of items [22].

On the other hand, the adjusted item-total score correlation coefficients, also known as homogeneity indices or discrimination indices and that represent the contribution of each statement to the whole instrument, put all of them above 0.30, a value set as satisfactory by some authors [38]. Therefore, the high correlation which has been found among items suggests that the concept has been measured with a high level of reliability 
in the sample. It is worth stressing that the reliability of an instrument may vary depending on the specific sample on which it is applied. The internal consistency reliability of the instrument in other languages has shown Cronbach's $\alpha$ value between 0.93 and 0.66 $[3,10,12,14]$, close to those found in our study. In particular, the Chinese translation of CMFS showed a Cronbach's $\alpha$ value of 0.81 [17]. In the Thai version, the test-retest reliability coefficient was 0.80 [19]. Hence, the value for the Cronbach's $\alpha$ coefficient obtained in this study indicates that the Spanish version of CMFS had an acceptable internal consistency.

As for reliability, it should be highlighted that this is not the property of an instrument but the property of an instrument administered to a specific sample, under specific conditions, in this case, a group of children between 6 and 10 years old from 4 schools in the north of Spain [37]. Consequently, it is important to continue using this Spanish version of the CMFS-R scale in other studies, with other samples, in other contexts and evaluate its reliability in them. Additionally, in order to complete the psychometric evaluation of the Spanish version of the CMFS-R, future studies should analyse additional psychometric properties such as criterion validity or test-retest validity.

In their review, Foster and Park [12] identified potential disadvantages of the CMFS$\mathrm{R}$ due to its limited psychometric support in terms of criterion, discriminant and construct validity and the insufficient testing performed with children from different cultural backgrounds. Our study helps compensate some of these limitations, as its validity has been proven in the Spanish culture. Furthermore, the results of our study offer additional evidence about the construct validity of this instrument.

The present study contributes to a better understanding of the medical fear experienced by children during medical visits or when performing procedures, which can have short- and long-term consequences on their physical and mental health $(1,39,40)$. It is related to patients' negative results as a delay in recovery, increase in the pain level or greater likelihood of infection [12]. Given that it is such a frequent emotional response among the infant population, it is advisable that health professionals consider and handle it properly through healthcare for the paediatric population. Therefore, it is essential to find a convenient and evidence-based assessment tool to improve knowledge on this phenomenon. Using a reliable measuring instrument can also make it possible to evaluate the efficacy of the interventions designed to reduce the degree of medical fear in children. This study offers a valid and reliable instrument that can be used both in the clinical field and in research in the Spanish context, to score children's fear in the medical environment.

\section{Conclusions}

This study presents a Spanish version of the CMFS-R scale that reports an acceptable level of validity and reliability, but that requires further studies in other contexts and with other samples that help to reinforce the results obtained regarding the psychometric characteristics of the scale. The use of a valid instrument to measure medical fear in the paediatric population is essential both in the clinical field and in research, to determine interventions intended to improve this negative experience suffered by many children in contact with the healthcare context and relations with medical and nursing staff.

Author Contributions: All the authors contributed significantly to the preparation of this manuscript; Conceptualization, LSM, PEH, NSR; methodology, LSM, PEH, NSR, MFT, ASG, CGV; validation, LSM, PEH, NSR, MFT, ASG, CGV; formal analysis, LSM, PEH, NSR, MFT, ASG, CGV; investigation, LSM, PEH, NSR, MFT, ASG, CGV; resources, LSM, PEH, NSR, MFT, CGV; data curation, LSM, ASG; writing-original draft preparation, LSM, PEH, NSR, MFT, ASG, CGV; writing-review and editing, LSM, PEH, NSR, MFT, ASG, CGV; visualization, LSM, PEH, NSR, MFT, ASG, CGV; supervision, LSM, PEH, NSR, MFT, ASG, CGV; project administration, LSM; funding acquisition, LSM, PEH, NSR, MFT. All authors have read and agreed to the published version of the manuscript." 
Funding: This work was supported by the Department of Education of the Government of Navarre (Grant No. CENEDUCA4/2019).

Institutional Review Board Statement: "The study was conducted according to the guidelines of the Declaration of Helsinki, and approved by the Committee of Ethics, Animal Experimentation and Biosafety of the Public University of Navarre (protocol code IP-030/19; date of approval: 11/18/2018)."

Informed Consent Statement: "Informed consent was obtained from all subjects involved in the study."

Acknowledgments: We thank schools, parents and childrens who completed the questionnaire and for its valuable collaboration.

Conflicts of Interest: "The authors declare no conflict of interest."

\section{Appendix A. "Child Medical Fear Scale” in Spanish.}

INSTRUCCIONES PARA LOS NIÑOS: Te voy a hacer unas preguntas sobre lo que piensas cuando estás enfermo, vas a un médico o vas al hospital. Quiero que me digas hasta qué punto te da miedo cada una de las frases que te voy a leer. Por ejemplo, si digo “Tengo miedo a vomitar si me pongo malo", quiero que me digas si no tienes nada de miedo, si tienes un poco de miedo o mucho miedo de vomitar cuando estás malo. ¿De acuerdo? ¿Quieres preguntarme algo antes de empezar?

\begin{tabular}{cccc}
\hline Nada de & Un poco & Mucho \\
miedo miedo & de miedo & mied \\
\hline
\end{tabular}

1. Tengo miedo a hacerme daño.

2. Tengo miedo a ir a la consulta del médico.

3. Tengo miedo a que me pinchen.

4. Tengo miedo a ver cómo me sale sangre.

5. Tengo miedo a ir al hospital.

6. Tengo miedo de que me pinchen en el dedo.

7. Tengo miedo a que los médicos y las enfermeras no me digan lo que me van a hacer.

8. Tengo miedo a vomitar.

9. Tengo miedo a no ir al colegio si me pongo malo.

10. Tengo miedo a llorar cuando me hagan daño.

11. Si voy al hospital, tengo miedo a tener que quedarme mucho tiempo allí.

12. Tengo miedo a contagiar a mi familia o amigos si estoy enfermo y juego con ellos.

13. Tengo miedo a morirme si voy al hospital.

14. Tengo miedo cuando el médico o la enfermera miran mi garganta

15. Tengo miedo a que el médico o la enfermera me digan que me pasa algo malo.

16. Tengo miedo a estar lejos de mi familia si voy al hospital.

17. Tengo miedo cuando el médico o la enfermera apoyan el palito en mi lengua. 


\section{References}

1. Dalley JS, McMurtry CM. Teddy and I get a check-up: a pilot educational intervention teaching children coping strategies for managing procedure-related pain and fear. Pain Research and Management [Internet]. 2016;2016:1-12. Available from: http://www.hindawi.com/journals/prm/2016/4383967/

2. McMurtry CM, Pillai Riddell R, Taddio A, Racine N, Asmundson GJG, Noel M, et al. Far From "Just a Poke": Common Painful Needle Procedures and the Development of Needle Fear. The Clinical journal of pain. 2015 Oct;31(10 Suppl):S3-11.

3. Hart D, Bossert E. Self-reported fears of hospitalized school-age children. Journal of Pediatric Nursing. 1994 Apr;9(2):83-90.

4. Salmela M, Salanterä S, Aronen ET. Coping with hospital-related fears: experiences of pre-school-aged children. Journal of Advanced Nursing [Internet]. 2010 Jun;66(6):1222-31. Available from: http://doi.wiley.com/10.1111/j.1365-2648.2010.05287.x

5. Salmela M, Aronen ET, Salanterä S. The experience of hospital-related fears of 4- to 6-year-old children. Child: Care, Health and Development. 2011;37(5):719-26.

6. Nicastro EA, Whetsell MV. Children's fears. Journal of Pediatric Nursing [Internet]. 1999 Dec;14(6):392-402. Available from: https://linkinghub.elsevier.com/retrieve/pii/S0882596399800682

7. Steward MS, Steward DS. Children's conceptions of medical procedures. New Directions for Child and Adolescent Development [Internet]. 1981 Dec;1981(14):67-83. Available from: http://doi.wiley.com/10.1002/cd.23219811406

8. Broome ME, Hellier AP. School-Age Childrens Fears of Medical Experiences. Issues in Comprehensive Pediatric Nursing [Internet]. 1987 Jan 10;10(2):77-86. Available from: http://www.tandfonline.com/doi/full/10.3109/01460868709009015

9. Broome M, Hellier A, Wilson T, Dale S, Glanville C. Measuring children's fear of medical experiences. In: Waltz CF, Strickland OL, editors. Measurement of Nursing Outcomes: Vol: Measuring Client Outcomes. New York: Springer Publishing; 1988. p. 201-14.

10. Beyer JE, Knott CB. Construct validity estimation for the African-American and Hispanic versions of the Oucher Scale. Journal of Pediatric Nursing [Internet]. 1998 Feb;13(1):20-31. Available from: https://linkinghub.elsevier.com/retrieve/pii/S0882596398800651

11. Broome M, Mobley T. The child medical fears scale. In: Strickland OL, Dilorio C, editors. Measurement of Nursing Outcomes Volumen 2: Client Outcomes and Quality Care. 2nd ed. New York: Springer Publishing Company; 2003. p. $196-205$.

12. Foster RL, Park J hwan. An Integrative Review of Literature Examining Psychometric Properties of Instruments Measuring Anxiety or Fear in Hospitalized Children. Pain Management Nursing [Internet]. 2012;13(2):94-106. Available from: http://dx.doi.org/10.1016/j.pmn.2011.06.006

13. Mahat G, Scoloveno M. Comparison of fears and coping strategies reported by Nepalese school-age children and their parents. Journal of Pediatric Nursing. 2003;

14. Wilson AH, Yorker B. Fears of medical events among school-age children with emotional disorders, parents, and health care providers. Issues in Mental Health Nursing. 1997;18(1):57-71.

15. Broome M, Bates TA, Lillis PP, McGahee TW. Children's medical fears, coping behaviour patterns and pain perceptions during a lumbar puncture. European Journal of Cancer Care [Internet]. 1994 Mar;3(1):31-8. Available from: http://doi.wiley.com/10.1111/j.1365-2354.1994.tb00007.x

16. Sparks L. Taking the "Ouch" Out of Injections for Children: Using Distraction to Decrease Pain. MCN: The American Journal of Maternal/Child Nursing. 2001;26(2).

17. Jin Y. Selected factors associated with medical fear among hospitalized Chinese school age children [Internet]. [Chiang Mai, Thailand]; 1997. Available from: http://cmuir.cmu.ac.th/jspui/handle/6653943832/29694

18. Abu-Saad HH, Pool H, Tulkens B. Further validity testing of the Abu-Saad Paediatric Pain Assessment Tool. Journal of Advanced Nursing. 1994;19(6):1063-71.

19. Chaiyawat W, Brown JK. Psychometric properties of the Thai versions of state-trait anxiety inventory for children and child medical fear scale. Research in Nursing and Health. 2000;23(5):406-14.

20. Brislin RW. Back-Translation for Cross-Cultural Research. Journal of Cross-Cultural Psychology. 1970;1(3):185-216.

21. Sperber AD. Translation and Validation of Study Instruments for Cross-Cultural Research. Gastroenterology. 2004;126(1):124-8.

22. Nunnally J. Psychometric theory. 3rd ed. New York: McGraw-Hill; 1994.

23. Hayduk LA. Structural equation modeling with LISREL. Essentials and advances. The Johns. Baltimore; 1987. 
24. Jöreskog KG. Structural equation modeling with ordinal variables using LISREL. Scientific. 2002.

25. Jöreskog KG. Testing structural equation models. In: Bollen KA, Long JS, editors. Newbury Park, CA: SAGE Publications; 1993. p. 294-312.

26. Muthén B. A general structural equation model with dichotomous, ordered categorical, and continuous latent variable indicators. Psychometrika. 1984;49(1):115-32.

27. Aroian KJ, Norris AE. Confirmatory factor analysis. In: Munro BH, editor. Statistical methods for health care research. 5th ed. Philadelphia: Lippincott Williams \& Wilkins; 2005. p. 351-75.

28. Rial A, Varela J, Abalo J, Lévy J. El análisis factorial confirmatorio. In: Lévy J, Varela J, editors. Modelización con estructuras de covarianzas en ciencias sociales: temas esenciales, avanzados y aportaciones especiales. Netbiblo; 2006. p. 119-54.

29. Koller D. 'Kids need to talk too': inclusive practices for children's healthcare education and participation. Journal of Clinical Nursing [Internet]. 2017 Sep;26(17-18):2657-68. Available from: http://doi.wiley.com/10.1111/jocn.13703

30. Lööf G, Andersson-Papadogiannakis N, Silén C. Children's own perspectives demonstrate the need to improve paediatric perioperative care. Nursing Open [Internet]. 2019 Oct 18;6(4):1363-71. Available from: https://onlinelibrary.wiley.com/doi/abs/10.1002/nop2.332

31. American Psychiatric Association. Diagnostic and statistical manual of mental disorders (DSM-5®). American Psychiatric Pub; 2013.

32. de Mula-Fuentes B, Quintana M, Rimbau J, Martínez-Mejías A, Úriz MS, Rivera-Pérez C, et al. Anxiety, hospital fears and conduct and behavioral alterations during pediatric hospitalization. Actas espanolas de psiquiatria [Internet]. 2018;46(2):4250. Available from: http://www.ncbi.nlm.nih.gov/pubmed/29616712

33. Bray L, Appleton V, Sharpe A. The information needs of children having clinical procedures in hospital: Will it hurt? Will I feel scared? What can I do to stay calm? Child: Care, Health and Development [Internet]. 2019 Sep 18;45(5):737-43. Available from: https://onlinelibrary.wiley.com/doi/abs/10.1111/cch.12692

34. Bray L, Appleton V, Sharpe A. 'If I knew what was going to happen, it wouldn't worry me so much': Children's, parents' and health professionals' perspectives on information for children undergoing a procedure. Journal of Child Health Care [Internet]. 2019 Dec 20;23(4):626-38. Available from: http://journals.sagepub.com/doi/10.1177/1367493519870654

35. Wechter S. School-Age Children's Perception of Stress in the Hospital: A Draw and Tell Story [Internet]. 2014. Available from: https://digitalrepository.unm.edu/nurs_etds/20

36. Pedhazur EJ, Schmelkin LP. Measurement, design, and analysis: An integrated approach. Hillsdale, New Jersey: Lawrence Erlbaum Associates; 1991.

37. Polit DF, Beck CT. Nursing research: Principles and methods. 7th ed. Philadelphia: Lippincott Williams \& Wilkins; 2004.

38. Ebel RL, Frisbie DA. Essentials of educational measurement. Englewood Cliffs, NJ: Prentice-Hall; 1986.

39. Jaaniste T, Hayes B, von Baeyer CL. Providing children with information about forthcoming medical procedures: a review and synthesis. Clinical Psychology: Science and Practice [Internet]. 2007 Jun;14(2):124-43. Available from: http://doi.wiley.com/10.1111/j.1468-2850.2007.00072.x

40. Taddio A, Ipp M, Thivakaran S, Jamal A, Parikh C, Smart S, et al. Survey of the prevalence of immunization non-compliance due to needle fears in children and adults. Vaccine [Internet]. 2012 Jul;30(32):4807-12. Available from: https://linkinghub.elsevier.com/retrieve/pii/S0264410X1200686X 